\title{
Model of Corporate Value Improvement Through Investment Opportunity in Manufacturing Company Sector
}

\author{
Imam Faozi, Nunung Ghoniyah
}

Department of Management, Faculty of Economics, Universitas Islam Sultan Agung (UNISSULA), Jl. Kaligawe Raya Street Km.4, Semarang, 50112, PO Box 1054/SM, Indonesia

\begin{tabular}{|c|c|}
\hline ARTICLE INFO & A B S T RACT \\
\hline $\begin{array}{l}\text { Kata Kunci: } \\
\text { Nilai perusahaan, } \\
\text { kepemilikan institusional, } \\
\text { profitabilitas, } \\
\text { kebijakan pendanaan, } \\
\text { kebijakan dividen, } \\
\text { kesempatan investasi. }\end{array}$ & $\begin{array}{l}\text { This study aims to analyze the significance of the direct and indirect effect of } \\
\text { institutional ownership (INST), profitability (ROI), funding policy (DER), and } \\
\text { dividend policy (Tobin's Q) through investment opportunity (MV/BVE). The } \\
\text { research data used } 21 \text { samples of manufacturing companies listed on the } \\
\text { Indonesia Stock Exchange (IDX) during the } 2012-2016 \text { period. Data analysis } \\
\text { used path analysis with the help of EViews } 9 \text { and Sobel test to know the effect of } \\
\text { investment opportunity as an intervening variable. The interpretation findings } \\
\text { of the first line analysis model show that Profitability directly affects positively } \\
\text { and significantly on Corporate Value. Whereas, based on second-line analysis } \\
\text { model, Funding Policy and Dividend Policy indirectly have significant effects } \\
\text { on Corporate Value through Investment Opportunity variable. Simultaneously, } \\
\text { all independent variables affect } 97.45 \% \text { of Investment Opportunities and } \\
\text { amounted to } 97.97 \% \text { of Corporate Value through Investment Opportunities. }\end{array}$ \\
\hline
\end{tabular}

SARI PATI

Penelitian ini bertujuan menganalisis signifikansi pengaruh langsung dan tidak langsung variabel kepemilikan institusional (INST), profitabilitas (ROI), kebijakan pendanaan (DER), dan kebijakan dividen (DPR) terhadap nilai perusahaan (Tobin's Q) melalui kesempatan investasi (MV/BVE). Data penelitian menggunakan sampel 21 perusahaan sektor manufaktur yang terdaftar di Bursa Efek Indonesia (BEI) selama periode 2012-2016. Analisa data menggunakan analisis jalur dengan bantuan eviews 9 dan uji sobel untuk mengetahui pengaruh kesempatan investasi sebagai variabel intervening. Hasil interpretasi model analisis jalur pertama menunjukkan bahwa Profitabilitas secara langsung berpengaruh positif dan signifikan terhadap Nilai Perusahaan. Sedangkan berdasarkan model analisis jalur kedua, Kebijakan Pendanaan dan Kebijakan dividen secara tidak langsung berpengaruh signifikan terhadap Nilai Perusahaan melalui variabel Kesempatan Investasi. Secara simultan, semua variabel independen berpengaruh sebesar 97,45\% terhadap Kesempatan Investasi dan sebesar 97,97\% terhadap Nilai Perusahaan melalui Kesempatan Investasi. 


\section{INTRODUCTION}

Modern go public company has a goal of creating stock value as one of its main goals, because it reflectsthe company's ability in achieving expected profit, sales growth, and capital increase. High company stock value will also increase corporatevalue and eventually, stockholders' prosperity is also higher. Future investors see corporate value as one of the most important variables to assess company as a whole (Cheung, Chung, \& Fung, 2015).

In Indonesia, the movement of stock values (stock prices) of go public companies can be reflected comprehensively by the Indonesia composite index (ICI/IDX Composite/IHSG Indeks Harga Saham Gabungan in Indonesian). In the end of 2018 the ICI was IDR 6,194, this amount showed the worst performance in the last 3 years with minus $2.54 \%$ in the transition. Meanwhile in the previous year the ICI gave returns of $19.99 \%$ in 2017 , closing at Rp $6,355.65$, and recorded a gain of $15.32 \%$ in 2016 at a value of $\operatorname{Rp} 5,296.71$.

There are many factors affecting this corporate value, either positively or negatively, from external and internal. As for the internal factors include institutional ownership, proftability, funding policy, dividend policy, and investment decision. The large portion of ownership by institutional investors is believed to be able to minimize agency conflict and be able to monitor and control management performance, so that the stock value can increase (Alfaraih, Alanezi, \& Almujamed, 2012). Nevertheless research in the next period shows the opposite (Mokhtari \& Makerani, 2013), even an indication of having a great ability to monopolize by the institutional shareholders as the majority investor is considered to be able to reduce the market value itself (Hermuningsih, 2013).

The high profitability of corporate companies not only shows the good performance of the company but also provides an overview of the benefits that shareholders can have. In the end, the good performance will be reflected in the community's assessment of the company, which is seen from the better corporate values (Akinlo \& Asaolu, 2012; Rizqia, Aisjah, \& Sumiati, 2013; Sajid, Mahmood, \& Sabir, 2016). Conversely, high debt levels (leverage) tend to threaten investment from investors, which can reduce the value of the company on the stock exchange. So that it can be said that the market will respond better to companies that have low debt levels (Adenugba, Ige, \& Kesinro, 2016; Rahim, Yaacob, Alias, \& Nor, 2010). While dividend policy is one of the important instruments that become one of the sources of investor income, so the existence of such dividends can also increase the value of the company (Budagaga, 2017; Emamalizadeh, Ahmadi, \& Pouyamanesh, 2013; Rizqia et al., 2013).

Based on the previous research gap between institutional ownership and dividend policy on corporate value, this study adds investment opportunity as an intervening variable. Investment Opportunity Set (IOS) is an investment option or future growth opportunity for companies which is expected to generate high enough returns. Growing companies will select many investment opportunities as a way to grow the companies. Most equity market values are taken into account by growth opportunities, as well as empirical results indicate that growth opportunities affect corporate policy decisions (Riahi-Belkaoui, 2000, p. 37).

According to the description of the background above, the problem of the study deals with how to improve corporate value through institutional ownership, profitability, funding policy, dividend policy, andinvestment opportunities. In addition, the purpose of this study is to analyze the effect of institutional ownership , profitability, funding policy, dividend policy on investment opportunities and corporate value.

\section{LITERATURE REVIEW}

\section{Corporate value}

Corporate value of a company can be assessed through its stock price. Stock value is a reflection 
of the company's ability to achieve expected profit, sales growth, and capital increase. Thus, if the stock value of a company is high, then its value will be high too. Corporate value can be measured using Tobin's Q, which is the total of stock market value and leverage market value divided by the value of company's asset book. Tobin's $Q$ is used to measure the amount of corporate value through potentially increasing stock prices, potential management of company's financial management, and potential investment opportunities that will grow (Wolfe \& Sauaia, 2003).

\section{Institutional ownership}

Institutional ownership is a very important mechanism of external governance. This group of investors is in a position to affectpractices adopted by the company and their presence can lead to changes in company performances. This is because monitoring is more effectively done by institutional investors themselves.

(Jung \& Kwon, 2002) findings showedthat institutional ownership hasa positive and significant effect on corporate value. The same conclusion is also shown by (Alfaraih et al., 2012) that there is a positive and significant correlation between institutional ownership and corporate value. Based on the findings of previous studies, it can be hypothesized:

H1: Institutional ownership has a positive and significant impact on corporate value

\section{Profitability}

Profitability is a measurement of efficiency and overall performance of a company, as well as a measurement to assess a company's ability to generate profits (Nix \& Chen, 2013). Companies with an annual increasing rate of profit will give a high profit to stockholders. The company's profits will have an impact on stock value that will eventually increase corporate value (Sajid et al., 2016).

(Rizqia et al., 2013) concluded that profitability has a significantly positive correlation with corporate value. The same findings are also deduced by (Akinlo \& Asaolu, 2012), as well as (Hermuningsih, 2013).Therefore, based on the previous research findings, hypothesis can be made as:

H2: Profitability has a positive and significant effect on corporate value

\section{Funding Policy}

Funding policy goes hand in hand with investment decision because a company needs sufficient funds to support its investment activities. Capital structure refers to financing sources used by a company. Capital sources have important consequences for the company and can affect its value and its stockholders' wealth. Leverage is the cheapest form of capital, but the effect of high leverage increases will also increase financial risk. Leverage does not only increase the default risk for the company, but also increases the company's revenue volatility per share and return on equity (Baker \& Martin, 2011, pp. 1-2). There are several theories concerning capital structure, namely tradeoffs and packing order theories.

Earlier studies revealed that there is a significant positive effect between leverage and corporatevalue (Alonso, De, Iturriaga, \& Rodryguez, 2005; Altan \& Arkan, 2011; Rahim et al., 2010). Based on Cuong and Canh's findings (2012), it is shown that the use of leverage to some extent willgive effects, both positive and negative, to corporate value. The reserach findings of (Adenugba et al., 2016; Ahn, Denis, \& Denis, 2006; Aivazian, Ge, \& Qiu, 2005; Odit \& Chittoo, 2008) deduced that the use of leverage has a negative and significant effect on corporate value. Based on those findings, it can be hypothesized:

H3: Funding policy has a significant effect on company value

\section{Dividend Policy}

Company's dividend policy is a financing decision which affectsthe company's revenue amount, 
whereby the company decides whether to distribute profits to stockholders or to retain and reinvest the profits. Dividend policy refers to the dividend payout policy followed by the company in determining the total amount and distribution pattern of such dividend payments to stockholders from time to time. The dividend policy will affect stockholders' wealth and the company's ability to maintain revenue to exploit the growth of investment opportunities (Baker, 2009, p. 3). There are several theories on dividend policy, such as Dividend Irrelevance Theory, Bird In The Hand, Tax Preference Theory, and Clientele Effect Theory.

(Rizqia et al., 2013) showed that there is a positive and significant correlation between dividend policy and corporate value. The correlation is based on information asymmetry. Investors do not have entire information owned by management. Any policies made may reflect information about the condition and performance of the company. The study of (Budagaga, 2017)'s also has the same findings that there is a significant positive effectof dividend payout oncorporate value. Based on the previous researches, hypothis can be made:

H4: Dividend policy has a positive and significant effect on corporatevalue

\section{Investment Opportunity}

Investment Opportunity Set (IOS) is a company's alternative investment in the future, which is expected to generate high enough returns. (Myers, 1997) explains that investment policy is an investment decision in the form of combination of assets owned by the company and future investment opportunities. The investment policy will affect corporate value. IOS is a company's opportunity to grow bigger in the future. However not all companies are able to use investment policy well, so they will tend to make higher expenses compared to the value of lost opportunity (RiahiBelkaoui, 2000). Wahal and Mc Connell (2000) found a positive relationship between institutional ownership and company investment in Research and development. Based on the findings ofprevious researches, a hypothesis can be made:

H5: Institutional ownership has a positive and significant effect on investment opportunities

The research findings conducted by (Hassanpoor \& Pourali, 2014) showed that profitability has a positive and significant effect on investment policy. The same research findings are also summarized by (Sajid et al., 2016) that profitability has a positive and significant impact on investment decisions. Based on the findings of previous researches, it can be hypothesized:

H6: Profitability has a positive and significant effect on investment policy

(Sajid et al., 2016) also suggested that leverage has a significant and negative impact on investment decisions. The research is in line with the research findings conducted by (Kallapur \& Trombley, 1999; Smith \& Watts, 1992), that growing companies tend to favor internal financing rather than leverage.

H7: Funding policy has a significant negative effect on investment policy

Research conducted (Rizqia et al., 2013; Subramaniam, Devi, \& Marimuthu, 2011) indicated that dividend policy has a negative and significant effect on investment opportunities. The findings of this study are in accordance with those of (Jensen, 1986)'s, claiming that dividend distribution has a negative effect on investment opportunities. Based on the previous researches, a hypothesis can be made:

H8: Dividend policy has a negative and significant effect on investment policy

Research findings belong to (Rahim et al., 2010; Rizqia et al., 2013) concluded that investment opportunity has a positive effect on corporate value. The findings are also in accordance with the 
research findings conducted by (Slater \& Zwirlein, 1996). Based on the previous researches, hypothesis can be drawn:

H9: Investment policy has a positive and significant impact on corporate value

\section{METHODS}

This study used data taken from companies' financial statements in manufacturing industry sector listed in the Indonesia Stock Exchange (IDX) during the 20122016 period. The population in this study was the companies listed in the Indonesia Stock Exchange in the 2012-2016 period and included in manufacturing industry sector. The sample used was on the basis of certain considerations and criteria, namely the company must be listed in the Indonesia Stock Exchange (IDX) in the period of 2012 -2016, the companies' financial statements must have been published on www.idx.co.id, dividend must be in the period of $2012-2016$, and the companies must have appropriate financial statement data to be used as independent variables in this study.

Variables in this study used institutional ownership profitability, funding policy, and dividend policy as independent variables. Whereas, corporate value was used as dependent variable, and investment opportunity was intervening variable.

Corporate Value: measured using Tobin's Q that is the total market value added with the total debt and compared with the total assets of the company using the following formula (Gamayuni, 2015):

$$
\text { Tobin's Q }=\frac{\text { Total market value }+ \text { Total Debt }}{\text { Total Assets }}
$$

Investment Opportunity Set (IOS): as intervening variable which can theoretically affect the relationship between independent variables and dependent variable into indirect relationship. Investment Opportunity was measured by Market to Book Value of Equity (MV/BVE ) with the calculation using the formula (Kallapur \& Trombley, 1999) as follows:

$$
\mathrm{MV} / \mathrm{BVE}=\frac{\begin{array}{l}
\text { Total number } \\
\text { of stock circulated } \mathrm{x} \text { stock price }
\end{array}}{\text { Total Equity }}
$$

Institutional ownership: is the total number of stocksowned by institutional investors and compared to all stockscirculation. Institutional opportunity was calculated using the following formula: Fitriyah and Hidayat (2011):

$$
\text { INST }=\frac{\text { Number of stock owned by institution }}{\text { Total Equity }}
$$

Profitability: measured using return on investment (ROI), which compared the amount of net profit after tax with total assets of the company. Profitability was calculated by the formula (Priatinah \& Kusuma, 2012):

$$
\text { Return on investation }=\frac{\text { Net Profit after tax }}{\text { Total Assets }}
$$

Funding Policy: measured using debt to equity ratio (DER), which is comparing the company's total debt with its own total capital, by using the following formula (Gamayuni, 2015):

$$
\text { Debt to Equity Ratio }=\frac{\text { Total Debt }}{\text { Total Equity }}
$$

Dividend Policy : measured using Dividend Payout Ratio (DPR), namely by the follwing formula (Agrawal \& Jayaraman, 1994; Gamayuni, 2015):

$$
\mathrm{DPR}=\frac{\text { Dividend per share }}{\text { Return per share }}
$$

\section{Regression Equation Model}

This study used panel data conducted by classic 
assumption test and hypothesis test, using eviews 9 program assistancehip. The classic assumption tests included muticolinierity and heteroscedasticity test.Normality test was done on the residue. Regression equation model made use of two models as follows:

\section{Model I :}

$\mathrm{Y} 1=\alpha+\beta 5 \mathrm{X} 1+\beta 6 \mathrm{X} 2+\beta 7 \mathrm{X} 3+\beta 8 \mathrm{X} 4+\beta 1$

$\mathrm{MV} / \mathrm{BVE}=\beta 5 \mathrm{INST}+\beta 6 \mathrm{ROI}+\beta 7 \mathrm{DER}$

$$
+\beta 8 \mathrm{DPR}+\varepsilon 1
$$

\section{Model II :}

$$
\begin{aligned}
\mathrm{Y} 2= & \alpha+\beta 1 \mathrm{X} 1+\beta 2 \mathrm{X} 2+\beta 3 \mathrm{X} 3+\beta 4 \mathrm{X} 4 \\
& +\beta 9 \mathrm{Y} 1+\varepsilon 2
\end{aligned}
$$

Tobin's $\mathrm{Q}=\beta 1 \mathrm{INST}+\beta 2 \mathrm{ROI}+\beta 3 \mathrm{DER}$

$$
+\beta 4 \mathrm{DPR}+\beta 9 \mathrm{MV} / \mathrm{BVE}+\varepsilon 2
$$

\section{RESULTS AND DISCUSSION}

\section{Selection of Regression Model}

Based on the result of Chow Test, each equation I and II showed a probability value for crosssection Chi-square at 0.000 and $0.000(<0.05)$, so the best model used was Fixed Effect (FE). The Hausman Test results for probability value of random cross-section of equation I and II, each showed a value of 0.000 and $0.0050(<0.05)$, so it could be concluded that the best model used was Fixed Effect (FE). In equation I and II conducted by Chow Test and Hausman Test with the results of the same model selection, namely Fixed Effect, so it was no need to do Langrangge Multiplier (LM) Test.

\section{Classic assumption test Multicollinearity Test}

Based on multicolinearity test results of equation I and II, it was obtained that the value of correlation coefficient between independent variables were all less than 0.80 . This showed that there was no multicollinearity on regression model of equation I and II.

\section{Heteroscedasticity Test}

Based on Glejser test results as shown in Table 4, the probability value of ROI variable on equation I was 0.0185 ( $>0.05$ ), which means, there was heteroscedasticity. Similarly, on equation II, the probability value of ROI variable was $0.0000(<0.05)$, so that there was heteroscedasticity. Therefore, equation I and II models were resolved using General Least Square (GLS) regression model.

The result of heteroscedasticity test by GLS method was assessed by comparing the value of sum squared residual weighted and sum squared resid unweight. The test result of GLS method on equation Iand II obtained that the values of sum squared resid weighted were respectively 424.4013 and 81.82222424 .4013 , while the values of sum squared resid unweight were respectively 549.7338 and 96.74014. These results indicated that the sum of squared residual weighted values were less than those of sum of the squared resid unweight values, so it can be concluded that the equation model I and II with GLS method did not have heteroscedasticity problems.

\section{Hypothesis testing}

The hypothesis testing of equation I and II regression model was done using GLS method, which can be seen in Table 1.

Based on the coefficient values, the regression model of equation I and II can be made as follows:

$$
\begin{aligned}
\text { MV/BVE }= & 3,2530 \mathrm{INST}+3,3029 \mathrm{ROI}+7,0481 \mathrm{DER} \\
+ & 0,2671 \mathrm{DPR}+\varepsilon 1 \\
\text { Tobin's Q }= & -0,6355 \mathrm{INST}+8,8102 \mathrm{ROI} \\
& -0,2316 \mathrm{DER}-0,0209 \mathrm{DPR} \\
& +0,1636 \mathrm{MV} / \mathrm{BVE}+\varepsilon 2
\end{aligned}
$$

Based on Table 1, the research model can be drawn as in Figure 1.

The testing result of path analysis on figure 1 , it is known that institutional opportunity variable had neither direct nor indirect effect on company value. This is because institutional ownership had neither significant effect on company value nor on 
Table 1. Hypothesis Testing Results of Fixed Effect Model of Equation I and II

\begin{tabular}{clccl}
\hline Hypothesis & \multicolumn{1}{c}{ Description } & Coefficient & Prob. & Result \\
\hline H1 & INST (X1) $\rightarrow$ Tobin's Q (Y2) & -0.6355 & 0.3067 & H1 rejected \\
H2 & ROI (X2) $\rightarrow$ Tobin's Q (Y2) & $8.8102^{*}$ & 0.0000 & H2 accepted \\
H3 & DER (X3) $\rightarrow$ Tobin's Q (Y2) & -0.2317 & 0.1248 & H3 rejected \\
H4 & DPR (X4) $\rightarrow$ Tobin's Q (Y2) & -0.0210 & 0.3335 & H4 rejected \\
H5 & INST (X1) $\rightarrow$ MV/BVA (Y1) & -3.2530 & 0.4168 & H5 rejected \\
H6 & ROI (X2) $\rightarrow$ MV/BVA (Y1) & $3.3029^{*}$ & 0.0347 & H6 accepted \\
H7 & DER (X3) $\rightarrow$ MV/BVA (Y1) & $7.0482^{*}$ & 0.0000 & H7 accepted \\
H8 & DPR (X4) $\rightarrow$ MV/BVA (Y1) & $0.2671^{*}$ & 0.0455 & H8 accepted \\
H9 & MV/BVA (Y1) $\rightarrow$ Tobin's Q (Y2) & $0.1637^{*}$ & 0.0000 & H9 accepted \\
\hline
\end{tabular}

Description: * Significant at alpha $5 \%$

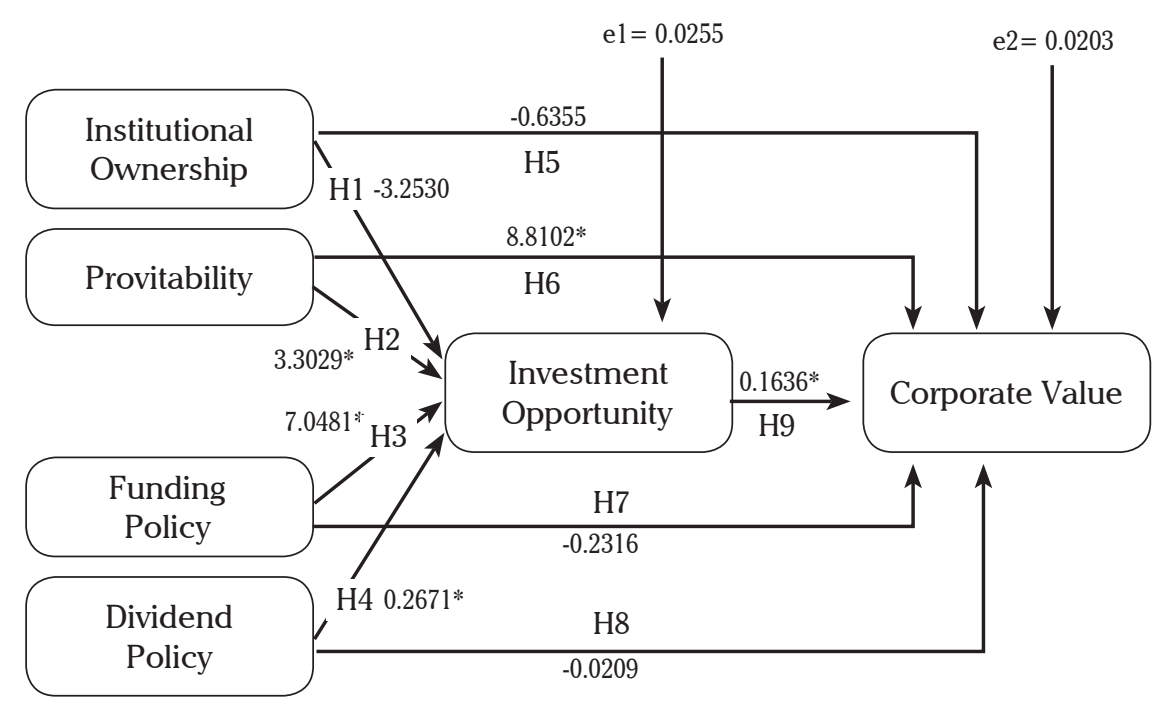

Figure1. Analysis Result of Research Model Path. * Significant at alpha 5\%

investment opportunity. Other results indicated that profitability, funding policy, and dividend policy indirectly affectedcorporate value through investment opportunities. However, it needed to be tested using Sobel Test, so the result shown Table 2 was obtained.

Table 2 shows the coefficient value of profitability indirect effect on corporate value through smaller investment opportunity compared to that of profitability direct effect on corporate value. So it can be concluded that profitability directly affected company value. The conclusion is that funding and dividend policy indirectly affect the value of the company through investment opportunity.

\section{Discussion}

The findings of this study are in accordance with those of (Mokhtari \& Makerani, 2013), which show that between institutional ownership and corporatevalue, there is no significant relationship. The findings of this study do not support the convergence argument from Jansen and Meckling (1976) which states that high institutional ownership will have an impact on increasing supervisory capability, thereby reducing agency problems between 
Tabel 2. Sobel Test Result of Indirect Effect of INST, ROI, DER, and DPR on Tobin's Q through MV/BVE

\begin{tabular}{lcccc}
\hline \multicolumn{1}{c}{ Variable } & $\begin{array}{c}\text { Coeff. } \\
\text { Indirect (axb) }\end{array}$ & SE Indirect & $\mathrm{t}$ - value & Ket. \\
\hline $\begin{array}{l}\text { Indirect effect of ROI to Tobin's } \\
\mathrm{Q} \text { through MV / BVE }\end{array}$ & 0.5406 & 0.26603 & 2.0321 & Significant \\
\hline $\begin{array}{l}\text { The indirect effect of DER to Tobin's Q } \\
\text { through MV / BVE }\end{array}$ & 1.1536 & 0.20273 & 5.6902 & Significant \\
\hline $\begin{array}{l}\text { The indirect effect of DPR to Tobin's Q } \\
\text { through MV / BVE }\end{array}$ & 0.0437 & 0.02265 & 1.9306 & Significant \\
\hline
\end{tabular}

Description: Significant at alpha 5\%

managers and stockholders. Institutional investors within the company can actively monitor and control management behavior through decisionmaking. Morck et al., (1988) in (Hermuningsih, 2013) stated that high institutional ownership will have an impact on decision-making power, which can then be disadvantaged to the interests of minority stockholders, resulting in a decline in stock prices.

Based on signaling hypothesis theory which explains the correlationbetween profitability and corporate value, high profitability gives a positive signal to stockholders that the company is in a good condition and able to produce profit. This condition is an attraction to investors to invest their stocks in the company, so that the value of the company will increase (Hermuningsih, 2013). Therefore, the findings of this study indicate that profitability has positive and significant effects on corporate value, which is in accordance with research by (Akinlo \& Asaolu, 2012; Gamayuni, 2015; Hermuningsih, 2013; Rizqia et al., 2013; Sucuahi \& Cambarihan, 2016).

The findings of this study are not in accordance with tax preferrence theory in relation to its capital structure, which states that the use of high debt levels will increase corporate value as a result of many tax benefits, which can be saved by the company. Modigliani and Miller (1958) in (Hermuningsih, 2013) argued that under the assumption of perfect capital markets, corporatevalueis irrelevantly determined by capital structure. Investors care more about the gains or losses of their stockholdings due to constant stock price changes. Therefore, the correction of stock prices will impact on corporate value. This theory explains the third hypothesis testing result that the funding policy has no effect on corporate value. This finding goes hand in hand with that of (Sulistiono, Moeljadi, Djazuli, \& Solimun, 2017).

Miller and Modigliani (1958) deduced that company's dividend policy in the perfect capital market is irrelevant affecting corporate value. This is because corporate value will be determined by the current cash flow and future capital investment decisions, not by how profits are shared as dividends or retained earnings. Miller and Modigliani also stated that investors naturally will not care about the choice between dividends and capital gains (Priya \& Mohansundari, 2016). Based on the hypothesis testing result, dividend policy has no effects on corporate value. This finding is in line with the that of (Khan, Nadeem, Islam, Salman, \& Gill, 2016; Sulistiono et al., 2017).

The condition of companies which is able to gain a stable profit will potentially invest in the future. This indicates that the company seizes the existing investment opportunities to further increase the company's profits in the future, thus giving trust to stockholders. Company managers believe that stockholders' satisfaction depends on the benefits they expect. Therefore, company managers seek to increase the company profits through investment 
policy in the future. This finding of this study goes with that of (Hassanpoor \& Pourali, 2014; Sajid et al., 2016), stating that profitability has positive and significant impacts on investment opportunities.

Investment opportunity as a company's growing standard is rated by the company management, concerning the types of funds that will be used, so that the use of debt significantly affect the company's investment opportunities. The finding of this study is consistent with the model of capital structure signaling theory which predicts that the use of debt is a positive signal to investors, stating that companies with higher leverage levels will show better stock market performance. This findingis in line with that of (Alonso, De et al., 2005; Cheng, Liu, \& Chien, 2010).

The dividend policy has significant positive effects on investment opportunities for the company. This indicates that the stockholders are given a certainty by the company in distributing a relatively constant dividend. In addition, the value of stock capitalization can be increased through a dividend policy that can be linked to investment by the company.

The utilization of investment opportunities by the company will have positive impacts on stock prices, thus increasing the company's growth as a basis for determining stock prices. Modigliani and Miller (1961) in (Hermuningsih, 2013) explained that company's ability in generating profits and capitalizing on great investment opportunities will be more decisive in stock price changes of companies, so positive and significant responses to stock prices will increase the value of the company. Therefore, investment opportunities have positive and significant impacts on corporatevalue, so this hypothesis is in line with the research findings conducted by (Rahim et al., 2010; Rizqia et al., 2013; Sulistiono et al., 2017).

\section{Theoretical Implications}

This research model has $R$-squared value on the first and second regression equation model, each earned 0.9745 and 0.9797 , so that all independent variables in this research were able to explain investment opportunity equal to $97,45 \%$, and able to explain company value equal to 97 . $97 \%$. This research model has been good, but institutional ownership variable has neither direct nor indirect significant effect on company value. Therefore, this research model can be used to develop the next researches.

\section{MANAGERIAL IMPLICATIONS}

The findings of this study indicate that Profitability directly affects Corporate Value. Profitability measures profit levels that can be generated by company. When the company profits increase, the stock prices will also increase, so that it will positively be responded by stockholders or investors. The rising stock price indicates that the company's stock is of high value, so the corporate value will be high as well. Therefore, the company's management needs to maximally improve the company's performance, so that will attract more investors to invest their shares into the company.

Funding and Dividend Policy indirectly affect Company Value onInvestment Opportunity. This suggests to management that when the Company's Dividend and Funding Policiesare used to increase the Corporate Value without considering investment opportunities, the findings obtained will not increase the Corporate Values according to management expectations. Therefore, the management should consider and use Investment Opportunities to increase their Company Value.

\section{CONCLUSION}

Based on the findings of this study, the regression equation models were used to explain that all independent variables jointly used were able to explain corporate value through investment opportunities in companies in manufacturing industry sector listed in the Indonesia Stock Exchange during 2012-2016 period, so this experiment can be deduced that: 
1. Institutional Ownership, Funding Policy and Dividend Policy have insignificant negative effects on Corporate Value. Once there is an increase in Institutional Ownership, Funding Policy, and Dividend Policy,Corporate Value will then decrease, but the decrease is insignificant.

2. Profitability and Investment Opportunity have positive and significant effects on Corporate Value. This suggests that if there is an increase in profitability, CorporateValue will also increase significantly.

3. Institutional Ownership has an insignificant negative effect on Investment Opportunities. Therefore, when there is an increase in Institutional Ownership, Investment Opportunity will then decrease insignificantly.

4. Profitability, Funding Policy, and Dividend Policy have positive and significant effects on Investment Opportunity. This suggests that if Profitability, Funding Policy, and Dividend Policy increase, Investment Opportunity will also then increase significantly .

5. Based on path analysis, Institutional Ownership, Funding Policy, and Dividend Policy cannot directly affect Corporate Value. However, only is Profitability able to directly affectCompany value.

6. Based on path analysis and Sobel Test, Funding Policy and Dividend Policy indirectly affect Corporate Value through Investment Opportunity. Therefore, if we do not consider the use of Investment Opportunity as an intervening variable, Funding and Dividend Policy will not affect Corporate Value.

\section{Limitations of the Research}

1. This study only used Institutional Ownership, Funding Policy, Dividend Policy and Investment Opportunities in assessing the increasing model of Corporate Value.

2. This study used 21 industrial companies of manufacturing sector with 5 years research period from 2012 to 2016 as its sample.

\section{Future Studies Agenda}

1. Future studies are expected to add other variables affecting Corporate Value, such as Good Corporate Growth, Corporate Social Responsibility, Managerial Ownership, and so on.

2. Future studies need to add the number of research samples and the time periods of the study.

3. Future studies need to add moderating variables on the effect between Dividend Policy and Corporate Value.

4. Future studies need to develop research models for other industry sectors in addition to manufacturing sectors, for example in the main sector industries (agriculture and mining sectors), or service industries (property, infrastructure, finance and trade). 
REFERENCES

Adenugba, A. A., Ige, A. A., \& Kesinro, O. R. (2016). Financial leverage and firms' value: a study of selected firms in Nigeria. European Journal of Business, Economics and Accountancy, 4(2), 1-19. Retrieved from http://www.idpublications.org/ ejbea-vol-4-no-2-2016/

Agrawal, A., \& Jayaraman, N. (1994). The Dividend Policies of All-Equity Firms: A Direct Test of the Free Cash Flow Theory. Managerial and Decision Economics, 15(2), 139-148. Retrieved from http://www.jstor.org/stable/2487787

Ahn, S., Denis, D. J., \& Denis, D. K. (2006). Leverage and Investment in Diversified Firms. Journal of Financial Economics, 79(2), 317-337. https://doi.org/10.1016/j.jfineco.2005.03.002

Aivazian, V. A., Ge, Y., \& Qiu, J. (2005). The Impact of Leverage on Firm Investment: Canadian Evidence. Journal of Corporate Finance, 11(1-2), 277-291. https://doi.org/10.1016/S0929-1199(03)00062-2

Akinlo, O., \& Asaolu, T. (2012). PROFITABILITY AND LEVERAGE: EVIDENCE FROM NIGERIAN FIRMS. Global Journal of Business Research, 6(1), 17-25. Retrieved from http://www.theibfr2.com/RePEc/ibf/gjbres/gjbr-v6n1-2012/GJBR-V6N1-2012-3.pdf

Alfaraih, M., Alanezi, F., \& Almujamed, H. (2012). The Influence of Institutional and Government Ownership on Firm Performance: Evidence from Kuwait. International Business Research, 5(10). https://doi.org/10.5539/ibr.v5n10p192

Alonso, De, A. P., Iturriaga, L. F. J., \& Rodryguez, J. A. S. (2005). Financial decisions and growth opportunities: a Spanish firm's panel data analysis. Applied Financial Economics, 15(6), 391-407. https://doi.org/10.2139/ssrn.250717

Altan, M., \& Arkan, F. (2011). Relationship Between Firm Value And Financial Structure: A Study On Firms In ISE Industrial Index. Journal of Business \& EconomicsResearch, 9(9), 61-65. https://doi.org/10.19030/jber.v9i9.5636

Baker, H. K. (2009). Dividends and Dividend Policy. New Jersey: John Wiley \& Sons, Inc. https://doi.org/10.1002/9781118258408. ch1

Baker, H. K., \& Martin, G. S. (2011). Capital Structure and Corporate Finance Decisions: Theory, Evidence, and Practice. New Jersey: John Wiley \& Sons, Inc. https://doi.org/10.1002/9781118266250

Budagaga, A. (2017). Dividend Payment and Its Impact on the Value of Firms Listed on Istanbul Stock Exchange: A Residual Income Approach. International Journal of Economics and Financial Issues2, 7(2), 370-376.

Cheng, Y.-S., Liu, Y.-P., \& Chien, C.-Y. (2010). Capital structure and firm value in China: A panel threshold regression analysis. African Journal of Business Management, 4(12), 2500-2507. Retrieved from http://www.academicjournals.org/AJBM

Cheung, W. M., Chung, R., \& Fung, S. (2015). The Effect of Stock Liquidity on Firm Value and Corporate Governance: Endogeneity and REIT Experiment. Journal of Corporate Finance2, 35, 211-231. https://doi.org/10.1016/j.jcorpfin.2015.09.001

Emamalizadeh, M., Ahmadi, M., \& Pouyamanesh, J. (2013). African Journal of Business Management Impact of financial leverage on dividend policy at Tehran Stock Exchange: A case study of food industry, 7(34), 3287-3296. https://doi. org/10.5897/AJBM12.650

Gamayuni, R. R. (2015). The Effect Of Intangible Asset, Financial Performance And Financial Policies On The Firm Value. INTERNATIONAL JOURNAL OF SCIENTIFIC \& TECHNOLOGY RESEARCH, 4, 1. Retrieved from www.ijstr.org

Hassanpoor, D., \& Pourali, M. R. (2014). The Relationship between Return on Equity and Investment Opportunities of the Firms Listed in Tehran Stock Exchange. Research Journal of Recent Sciences, 3(9), 10-14. Retrieved from www.isca.me

Hermuningsih, S. (2013). Profitability, Growth Opportunity, Capital Structure, and the Firm Value. Bulletin of Monetary, Economics, and Banking, 115-135. https://doi.org/10.21098/bemp.v16i2.440

Jensen, M. C. (1986). Agency Costs of Free Cash Flow, Corporate Finance, and Takeovers. The American Economic Review, 76(2), 323-329. Retrieved from https://sfinm.files.wordpress.com/2013/10/agency-costs-of-fcf-jensen.pdf

Jung, K., \& Kwon, S. Y. (2002). Ownership structure and earnings informativeness: Evidence from Korea. The International Journal of Accounting, 37(3), 301-325. https://doi.org/10.1016/S0020-7063(02)00173-5

Kallapur, S., \& Trombley, M. A. (1999). The Association Between Investment Opportunity Set Proxies and Realized Broth. Journal of Business and Accounting, 26(3), 505-519. https://doi.org/10.1111/1468-5957.00265

Khan, M. N., Nadeem, B., Islam, F., Salman, M., \& Gill, H. M. I. . (2016). Impact of Dividend Policy on Firm Performance: An Empirical Evidence From Pakistan Stock Exchange. American Journal of Economics, Finance and Management, 2(4), 28-34. Retrieved from http://files.aiscience.org/journal/article/pdf/70200100.pdf

Mokhtari, Z., \& Makerani, K. F. (2013). Relationship of Institutional Ownership with Firm Value andEarnings Quality: Evidence from Tehran Stock Exchange. International Journal of Economy, Management and Social Sciences, 2(7), 495-502.

Myers, M. D. (1997). Qualitative Research in Information Systems. MISQ Discovery. https://doi.org/10.2307/249422

Nix, P., \& Chen, J. . (2013). The Role of Institutional Investors in Corporate Governance (1st Ed). Hampshire: Palgrave Macmillan.

Odit, P. M., \& Chittoo, H. B. (2008). Does Financial Leverage Influence Investment Decisions? The Case of Mauritian Firms. Journal of Business Case Studies, 4(9), 49-60. https://doi.org/10.19030/jbcs.v4i9.4807

Priatinah, D., \& Kusuma, P. . (2012). Pengaruh Return On Investment (ROI), Earning Per Share (EPS), dan Dividen Per Share (DPS) Terhadap Harga Saham Perusahaan Pertambangan yang Terdaftar di Bursa Efek Indonesia (BEI) Periode 20082010. Jurnal Nominal, 1(1), 50-64. 
Priya, P. V., \& Mohansundari, M. (2016). Dividend Policy and Its Impact on Firm Value: A Review of Theories and Empirical Evidence. Apeejay- Journal of Management Sciences and Technology, 3(3), 59-69.

Rahim, A. R., Yaacob, H. M., Alias, N., \& Nor, M. F. (2010). Investment, Board Governance and Firm Value: A Panel Data Analysis. International Review of BusinessResearch Papers, 6(5), 293-302.

Riahi-Belkaoui, A. (2000). Accounting and the Investment Opportunity Set. Westport: Quorum Books. Retrieved from https:// books.google.co.id/books/about/Accounting_and_the_Investment_Opportunit.html?id=dpYch8zkIaUC\&redir_esc=y

Rizqia, D. A., Aisjah, S., \& Sumiati. (2013). Effect of Managerial Ownership, Financial Leverage, Profitability, Firm Size, and Investment Opportunity on Dividend Policy and Firm Value. Research Journal of Finance and Accounting, 4(11), 120 130. Retrieved from www.iiste.org

Sajid, M., Mahmood, $\dagger$---Amir, \& Sabir, ---Hazoor Muhammad. (2016). DOES FINANCIAL LEVERAGE INFLUENCE INVESTMENT DECISIONS? EMPIRICAL EVIDENCE FROM KSE-30 INDEX OF PAKISTAN Contribution/ Originality. Asian Journal of Economic Modelling, 4(2), 82-89. https://doi.org/10.18488/journal.8/2016.4.2/8.2.82.89

Slater, S. F., \& Zwirlein, T. J. (1996). The Structure of Financial Strategy: Patterns in Financial Decision Making. Journal of Managerial and Decision Economics, 17(3), 253-266. https://doi.org/DOI: 10.1002/(SICI)1099-1468(199605)17:3<253::AIDMDE750>3.0.CO;2-0

Smith, C. W., \& Watts, R. L. (1992). The investment opportunity set and corporate financing, dividend, and compensation policies. Journal of Financial Economics, 32(3), 263-292. https://doi.org/10.1016/0304-405X(92)90029-W

Subramaniam, R., Devi, S. S., \& Marimuthu, M. (2011). Investment opportunity set and dividend policy in Malaysia. African Journal of Business Management, 5(24), 10128-10143. https://doi.org/10.5897/AJBM11.687

Sucuahi, W., \& Cambarihan, J. M. (2016). Influence of Profitability to the Firm Value of Diversified Companies in the Philippines. Accounting and Finance Research, 5(2), 149. https://doi.org/10.5430/afr.v5n2p149

Sulistiono, S., Moeljadi, Djazuli, A., \& Solimun. (2017). Investment Opportunity Set as the Mediation Effect of Capital Structure, and Corporate Dividend Policy on Firm Value: A Study on Manufacturing Firms in Indonesia Stock Exchange. International Journal of Applied Business and Economic Research2, 15(22), 303-314.

Wolfe, J., \& Sauaia, A. C. A. (2003). The Tobin Q As A Company Performance Indicator. Developments in Business Simulation and Experimental Learning, 30, 155-159. Retrieved from https://journals.tdl.org/absel/index.php/absel/article/ viewFile/715/684 